\title{
Nutritional Quality of Olives and Olive oil Produced in the Serra Da Mantiqueira from Brazil
}

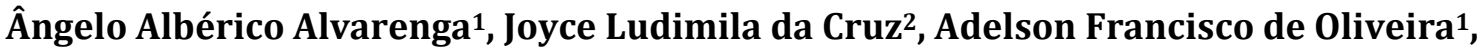 \\ Luiz Fernando de Oliveira da Silva ${ }^{1}$, Emerson Dias Gonçalves ${ }^{1}$, Paulo Márcio Norberto ${ }^{1}$ \\ ${ }^{1}$ Researchers/Scholarship BIP FAPEMIG/EPAMIG, Sul, Brazil \\ ${ }^{2}$ Scholarship PIBIC FAPEMIG/EPAMIG, Sul, Brazil \\ Email: angelo@epamig.br, adelson@epamig.ufla.br, Luiz.oliveira@epamig.br, emerson@epamig.br, paulonor@gmail.com, \\ joycenutri.cruz@gmail.com
}

How to cite this paper: Alvarenga, A.A., da Cruz, J.L., de Oliveira, A.F., de Oliveira da Silva, L.F., Dias Gonçalves, E. and Norberto, P.M. (2017) Nutritional Quality of Olives and Olive oil Produced in the Serra Da Mantiqueira from Brazil. Agricultural Sciences, 8, 518-526.

https://doi.org/10.4236/as.2017.87039

Received: April 4, 2017

Accepted: July 1, 2017

Published: July 4, 2017

Copyright $\odot 2017$ by authors and Scientific Research Publishing Inc. This work is licensed under the Creative Commons Attribution International License (CC BY 4.0).

http://creativecommons.org/licenses/by/4.0/

\begin{abstract}
The olive tree (Olea europaea L.) is one of the oldest fruits grown by man. Its fruit can be processed into olive oil or treated properly and serve directly for the in natura consumption in the form of olives. Extracted from the olive, the olive oil is highly valued in the market, for its nutritional benefits and also for its unique and delicate flavor. Brazil is the second largest importer of olive oil in the world, but technology is already available and the expansion of the crop has been taking place in the south-southeast regions, where the climate is favorable, in order to serve this market. The objective of this work was to evaluate the physical and chemical qualities of the olives and characterize, sensorially and chemically, olive oils from different olive cultivars planted in the Region of Serra da Mantiqueira. The olives and olive oils produced from the cultivars Arbequina, Arbosana, Grapolo 541, Koroneiki and Maria da Fé were evaluated at the EPAMIG Experimental Field of Maria da Fé, Minas Gerais, and Brazil. In the first experiment the olives harvested in February of 2015 were analyzed in terms of weight, volume, transverse and longitudinal diameter of the fruit and the lump and the relation of the olive/lump and the chemical (protein, lipid, moisture and ashes). In the second experiment the olives were processed by the grinding, beating and centrifugation method to obtain the oils. The olive oils were analyzed for acidity, peroxide index and absorbance in the ultraviolet region at $274 \mathrm{~nm}, 270 \mathrm{~nm}, 266 \mathrm{~nm}$ and $232 \mathrm{~nm}$. After this characterization the olive oils produced in the Serra da Mantiqueira were then submitted to sensorial analysis. The results were submitted to analysis of variance and the means were compared by the Tukey test at $5 \%$ of probability. The interpretation of the data from the sensorial analysis was done using the software sensomaker. Differences were observed between olives and olive oils
\end{abstract}


produced by different cultivars in the Serra da Mantiqueira. The cultivar Grappolo 541 produces larger fruits, indicated for the preparation of olives and in natura consumption. Due to the small size of the fruit, the cultivar Maria da Fé is more suitable for olive oil production. The oils of all cultivars are within the parameters established by the Brazilian legislation in force, being classified as Extra Virgin Olive Oil. The oils of all cultivars were well accepted by consumers, especially the cultivars Maria da Fé and Grappolo 541.

\section{Keywords}

Diet, Health, Diet, Cooking

\section{Introduction}

The olive tree (Olea europaea L.) together with the vine is one of the oldest fruits grown by man. Although there is some doubt, its cultivation is believed to have begun about 4000 years BC in the northern Dead Sea and spread to the West through the Mediterranean Sea [1].

Although olive trees have been introduced in Brazil for many decades, only in recent years have oliviculture started to arouse interest, especially among the businessmen and rural producers of the South of Minas, now based on technical and scientific knowledge generated by the experiences and researches made in its vast majority by the Agricultural Research Company of Minas GeraisEPAMIG [2].

Brazil is the second largest importer of olive oil in the world, with the United States the first and Canada the third in this classification [3]. It is estimated that for the supply of the domestic market, at current consumption levels, it would be necessary to plant 62,000 hectares, which could generate billions of $\mathrm{R} \$$ for the Brazilian economy, besides generating countless jobs in all the links of the productive chain [1].

The fruit of the olive tree can be processed and transformed into olive oil or treated properly and serve directly for the consumption in natura in the form of olives. The physico-chemical characteristics of the different cultivars determine their best destination, whether for olive production or olive production. The climate also directly interferes in these factors determining the final quality of the product. Oliveira [2] characterized 35 olive cultivars in the southern region of Minas Gerais agronomically and carpmetrically, concluding that all cultivars have great potentials, either for olive production or olive production, which can be classified as virgin or extra virgin. Olive oil is the main source of oleic acid in the diet, as well as being a source of several other substances that exert antioxidant activity in the body due to its phenolic compounds [4].

Olive oil is probably one of the oldest agricultural products recorded in history. Extracted from the olive, it is highly valued in the market, for its nutritional benefits and, also, for its unique and delicate flavor. The product represents the 
main edible oil of Mediterranean countries and is already an important commodity in other countries, such as New Zealand, Chile and the United States [5]. Due to its chemical constitution, its use brings health benefits, as they are rich in natural antioxidants, besides being a natural source of monounsaturated fatty acids [6]. Numerous studies have now provided evidence that nutrients and bioactive compounds in foods, such as olive oil, can contribute positively to disease prevention [7]. For these reasons, consumption of per capita olive oil is increasing worldwide and research has been carried out aiming at improving olive production techniques, obtaining olive oil and sensorial quality to obtain better quality products [1] [2] [8].

Brazilian legislation defines olive oil as a product derived solely from olives, extracted by physical or mechanical processes and cold, i.e., temperature not above $28^{\circ} \mathrm{C}$ [9].

The objective of this work was to evaluate the physical and chemical qualities of the olives and to characterize, sensorial and chemically, olive oils from different olive cultivars planted in the Brazilian region of "Serra da Mantiqueira".

\section{Material and Methods}

\section{Experiment 1: Evaluation of olives}

Homogeneous samples with approximately 500 grams of olives from five olive cultivars (Arbequina: Spanish cultivar origin, produces small fruit suitable for manufacturing olive oil; Arbosana: Spanish cultivar, similar to "Arbequina", produces small fruit suitable for manufacturing olive oil; Grappolo 541: Brazilian clone obtained from the Italian cultivar Grappolo, whose fruits can serve both for the production of olive oil and also for the consumption in natura; Koroneiki: Greek cultivar that produces fruits that give rise to a fruity olive oil spicy and slightly bitter; and Maria da Fé: Brazilian clone coming from the cultivar Galega of Portuguese origin, indicated for the manufacture of olive oil) were collected in February 2015 at the time of harvest. The plants are part of the cultivar collection of the Experimental Farm of the EPAMIG of Maria da Fé, MG, which is located in the South of Minas at an altitude of 1258 meters, presenting tropical climate type Cwb [10].

The fruits were frozen immediately after harvesting and transported in Styrofoam boxes to Lavras-MG, where they were analyzed at the Quality Laboratory of the "Dr. Alcides Carvalho" by EPAMIG.

For the carpet analysis, ten repetitions were made and the following characteristics were evaluated: weight, volume, transverse and longitudinal diameter of olive and the lump, and the ratio of olive/lump.

Regarding the chemical quality, analyzes of protein, lipid, moisture and ash contents were done for the five cultivars in triplicate.

The experiment consisted of 5 treatments (cultivars) distributed in 10 repetitions for the carpometric evaluation and in 3 repetitions for chemical evaluation of the constituents of the fruit. 
The results were submitted to analysis of variance and the means were compared by Tukey's test at $5 \%$ of probability, using statistical software Sisvar ${ }^{\circledR}$ [11].

\section{Experiment 2: Evaluation of olive oils}

This experiment was carried into the Department of Food Science (DCA) and the Center for Chemical Analysis and Prospecting (CAPQ), Department of Chemistry, Federal University of Lavras (UFLA), Lavras, MG.

The samples of olive oil were produced by the Agricultural Research Company of Minas Gerais (Epamig), from fruits harvested from olive trees with 8 years of age in the harvest in the year 2014/15. Olive oil samples from five different cultivars were used: A-Koroneiki; B-Arbequina; C-Maria da Fé; D-Grappolo 541; and E-Arbosana.

The oils were extracted in a continuous system of operation, which is divided into three stages: Crushing, thumping and spinning. After these steps the oil remains stored in stainless steel and are packed in amber or green glass bottles [1].

According to the rules established by current Brazilian legislation [12], olive oils must be subjected to chemical analysis in order to ascertain their quality and authenticity, so that it can be classified.

The determination of the acidity was carried out by titration with ethyl alcohol solution and phenolphthalein indicator, according to AOAC [13] and Adolfo Lutz Institute [14] and the result was expressed as \% oleic acid $(\mathrm{m} / \mathrm{m})$.

The peroxide content was determined by the Association of Official Analytical Chemists [13], for the ability of the peroxides present in the sample to oxidize potassium iodide. The results were expressed in meq $\mathrm{O}_{2} / \mathrm{Kg}$.

Specific extinction was determined by measuring the absorbance in the ultraviolet region at $274 \mathrm{~nm}, 270 \mathrm{~nm}, 266 \mathrm{~nm}$ and $232 \mathrm{~nm}$, using the methodologies of the Adolfo Lutz Institute [14].

After the physical and chemical characterization, the olive oils produced in the Serra da Mantiqueira were then submitted to sensory analysis. The sensorial analysis was carried out in the Laboratory of Sensory Analyzes of the Department of Food Sciences of the Federal University of Lavras by consumers. The oil samples of the 5 cultivars were evaluated by 50 evaluators for taste, visual appearance, odor and overall appearance.

The results were submitted to analysis of variance and the means were compared by the Tukey test at $5 \%$ of probability, using statistical software Sisvar ${ }^{\otimes}$ (FERREIRA, 2008). The interpretation of the data from the sensorial analysis was done using the methodology proposed by Pinheiro et al. [15].

\section{Results and Discussion}

\section{Experiment 1: Evaluation of olives}

The analysis of variance showed that there was a significant difference among the olive cultivars for all carpet characteristics evaluated.

Table 1 shows the results of the carpometric evaluations made on the five olive cultivars. 
In relation to the weight, volume and longitudinal and transverse diameters of the fruit, Grapollo 541 showed the highest values, showing its vocation for the production of table olives for in natura consumption, since for this purpose, the size of the fruit added large commercial value to the product. On the other hand, the cultivar Maria da Fé presented the lowest values for these characteristics, being the most suitable for the manufacture of olive oil. The other cultivars, although in an intermediate situation, are more adequate to the production of olive oil, because they present values closer to the cultivar Maria da Fé.

Table 2 shows the carpometric assessments of the olive stones of the 5 cultivars studied.

It is possible to observe a very large correlation between the values reached by the lumps in relation to those obtained previously for the olive, resulting in practically the same classification as in "Grappolo 541" with the highest values and "Maria da Fé" with the lowest, with the remaining cultivars being intermediate.

As for the pulp/lump ratio, due to this previously mentioned correlation, no statistical differences were observed among the cultivars, since the cultivar that presented the largest pulp, also presented the largest olive.

Table 1. Weight (WO, g), volume $\left(\mathrm{VO}, \mathrm{mm}^{3}\right.$ ), longitudinal diameter (LDO, $\mathrm{mm}$ ) e transverse diameter (TDO, mm) of olives from different olive cultivars. Epamig, Lavras, Minas Gerais, Brazil, 2016.

\begin{tabular}{ccccc}
\hline Cultivar & WO & VO & LDO & TDO \\
\hline Arbequina & $1.65 \mathrm{~b}$ & $1.76 \mathrm{~b}$ & $12.14 \mathrm{bc}$ & $14.38 \mathrm{bc}$ \\
Arbosana & $1.75 \mathrm{~b}$ & $1.87 \mathrm{~b}$ & $12.45 \mathrm{~b}$ & $13.93 \mathrm{c}$ \\
Grappolo 541 & $3.01 \mathrm{a}$ & $2.86 \mathrm{a}$ & $12.25 \mathrm{a}$ & $19.16 \mathrm{a}$ \\
Koroneiki & $1.35 \mathrm{bc}$ & $1.16 \mathrm{c}$ & $10.96 \mathrm{c}$ & $15.44 \mathrm{~b}$ \\
Maria da Fé & $0.95 \mathrm{c}$ & $0.88 \mathrm{c}$ & $9.39 \mathrm{~d}$ & $13.02 \mathrm{c}$ \\
C.V (\%) & 21.28 & 19.44 & 8.27 & 7.68 \\
\hline
\end{tabular}

Means followed by the same letter in the columns do not differ from each other by the Tukey test at $5 \%$ probability.

Table 2. Weight (WL, g), volume (VL, $\left.\mathrm{mm}^{3}\right)$, longitudinal diameter (LDL, $\mathrm{mm}$ ) e transverse diameter (TDL, mm) of lump and Ratio olive/lump (ROL) from different olive cultivars. Epamig, Lavras, Minas Gerais, Brazil, 2016.

\begin{tabular}{cccccc}
\hline Cultivar & WL & VL & LDL & TDL & ROL \\
\hline Arbequina & $0.40 \mathrm{~b}$ & $0.55 \mathrm{a}$ & $7.33 \mathrm{~b}$ & $10.43 \mathrm{bc}$ & $0.75 \mathrm{a}$ \\
Arbosana & $0.38 \mathrm{~b}$ & $0.44 \mathrm{ab}$ & $7.10 \mathrm{~b}$ & $10.65 \mathrm{bc}$ & $0.77 \mathrm{a}$ \\
Grappolo 541 & $0.59 \mathrm{a}$ & $0.55 \mathrm{a}$ & $8.00 \mathrm{a}$ & $13.83 \mathrm{a}$ & $0.80 \mathrm{a}$ \\
Koroneiki & $0.26 \mathrm{c}$ & $0.45 \mathrm{ab}$ & $5.90 \mathrm{c}$ & $11.02 \mathrm{~b}$ & $0.79 \mathrm{a}$ \\
Maria da Fé & $0.23 \mathrm{c}$ & $0.33 \mathrm{~b}$ & $5.76 \mathrm{c}$ & $9.63 \mathrm{c}$ & $0,77 \mathrm{a}$ \\
C.V (\%) & 24.22 & 33.30 & 6.50 & 9.90 & 5.18
\end{tabular}

Means followed by the same letter in the columns do not differ from each other by the Tukey test at $5 \%$ probability. 
However, it is necessary to consider the chemical and productive characteristics of the cultivars in order to be able to define their vocation for the production of olive oil, olive, or for both purposes.

For the quantified chemical characteristics, the analysis of variance also showed significance among all analyzed characteristics. Table 3 shows the values of moisture, ash, lipids and proteins found in the olives of the different olive cultivars in the 2014/15 harvest.

Regarding moisture, the highest content was observed in "Koroneiki" (59.8\%) and lowest in "Maria da Fé" (54.56\%), which was statistically detected due to the low coefficient of variation $(\mathrm{CV}=0.56 \%)$, very common in laboratory analysis, where the conditions are quite homogeneous between the repetitions (triplicate).

Regarding the contents of ashes and proteins, the cultivar Maria da Fé was highlighted, with the highest values among the others. As for the lipid contents, the highest values were found in "Grappolo 541" and "Koroneiki".

The work carried out by Silva [1] also detected differences in the olives harvested in the same collection in previous years, but which provided the elaboration of excellent quality olive oil, classified as virgin and extra virgin.

\section{Experiment 2: Evaluation of olive oils}

The acid value in oleic acid ranged from $0.29 \%$ ("Arbequina") to $0.65 \%$ ("Maria da Fé") (Table 4). This index reflects directly on the quality of olive oil, especially on post-harvest care, using healthy fruits and fast processing. In order for the oil to be classified as extra virgin it must have a maximum acidity of $0.8 \%$, according to the norms established by the current Brazilian legislation [16].

However, it is important to note that this parameter can be changed according to time and storage conditions [9] [12].

The peroxide index presented results ranging from $7.18 \mathrm{mmol}_{\mathrm{c}} \cdot \mathrm{kg}^{-1}$ ("Koroneiki") to $11.61 \mathrm{mmol}_{\mathrm{c}} \mathrm{kg}^{-1}$ ("Maria da Fé"). This index refers to the same cares observed for the acidity, being measured how much oxidized the oil is, being considered extra virgin which presents up to 20 meq of $\mathrm{O}_{2}$ per $\mathrm{kg}$ of olive oil.

It is important to emphasize that there is no obligation to express on the label both the acid value and the peroxide index, since it is understood that the oil that has the label extra virgin already has these indexes within the maximum

Table 3. Centesimal composition of olives of different olive cultivars. Epamig, Lavras, Minas Gerais, Brazil, 2016.

\begin{tabular}{ccccc}
\hline Cultivar & Humidity (\%) & Ashes (\%) & Lipid (\%) & Protein (\%) \\
\hline Arbequina & $56.88 \mathrm{~b}$ & $1.20 \mathrm{~b}$ & $13.31 \mathrm{~b}$ & $2.55 \mathrm{~b}$ \\
Arbosana & $57.41 \mathrm{~b}$ & $1.15 \mathrm{~b}$ & $13.65 \mathrm{~b}$ & $2.18 \mathrm{c}$ \\
Grappolo 541 & $56.65 \mathrm{~b}$ & $1.15 \mathrm{~b}$ & $16.21 \mathrm{a}$ & $2.61 \mathrm{ab}$ \\
Koroneiki & $59.80 \mathrm{a}$ & $1.11 \mathrm{~b}$ & $16.28 \mathrm{a}$ & $2.42 \mathrm{bc}$ \\
Maria da Fé & $54.56 \mathrm{c}$ & $1.45 \mathrm{a}$ & $9.58 \mathrm{c}$ & $2.91 \mathrm{a}$ \\
C.V (\%) & 0.56 & 2.87 & 3.8 & 3.44 \\
\hline
\end{tabular}

Means followed by the same letter in the columns do not differ from each other by the Tukey test at $5 \%$ probability. 
Table 4. Chemical analysis of olive oil extracted from olive cultivars. Epamig, Lavras, Minas Gerais, Brazil, 2016.

\begin{tabular}{|c|c|c|c|c|c|c|}
\hline \multirow{2}{*}{ Cultivar } & \multirow{2}{*}{$\begin{array}{c}\text { Acidity } \\
(\%)\end{array}$} & \multirow{2}{*}{$\begin{array}{c}\text { Peroxide } \\
\left(\text { meq } 0_{2} / \mathrm{kg}\right)\end{array}$} & \multicolumn{4}{|c|}{ Absorbance (nm) } \\
\hline & & & 232 & 266 & 270 & 274 \\
\hline Koroneiki & $0.418 \mathrm{ab}$ & $7.653 \mathrm{a}$ & $0.650 \mathrm{a}$ & $0.105 \mathrm{ab}$ & $0.104 \mathrm{ab}$ & $0.101 \mathrm{ab}$ \\
\hline Arbequina & $0.294 \mathrm{a}$ & $11.402 \mathrm{~b}$ & $0.674 \mathrm{a}$ & $0.108 \mathrm{ab}$ & $0.108 \mathrm{ab}$ & $0.104 \mathrm{ab}$ \\
\hline Maria da Fé & $0.584 \mathrm{c}$ & $11.441 \mathrm{~b}$ & $0.791 \mathrm{a}$ & $0.150 \mathrm{~b}$ & $0.142 \mathrm{~b}$ & $0.137 \mathrm{~b}$ \\
\hline Grappolo 541 & $0.545 \mathrm{bc}$ & $9.121 \mathrm{ab}$ & $0.600 \mathrm{a}$ & $0.091 \mathrm{a}$ & $0.089 \mathrm{a}$ & $0.087 \mathrm{a}$ \\
\hline Arbosana & $0.317 \mathrm{a}$ & $11.019 \mathrm{~b}$ & $0.778 \mathrm{a}$ & $0.110 \mathrm{ab}$ & $0.110 \mathrm{ab}$ & $0.107 \mathrm{ab}$ \\
\hline CV (\%) & 11.61 & 10.00 & 18.02 & 15.77 & 15.25 & 14.91 \\
\hline
\end{tabular}

Means followed by the same letter in the columns do not differ from each other by the Tukey test at $5 \%$ probability.

parameters established by the legislation, Ie acidity of less than $0.8 \%$ and peroxide of less than $20 \mathrm{meq} \mathrm{O}_{2} / \mathrm{kg}$. However, if the producer wishes to express the acidity, it must be accompanied by the peroxide index.

The absorbance at ultraviolet at $232 \mathrm{~nm}$ ranged from 0.501 in the Arbequina cultivar to 0.972 in the cultivar Maria da Fé. For absorbance at wavelength at 270 $\mathrm{nm}$ there was variation of 0.083 for Koroneiki cultivar at 0.126 for Arbosana.

All the olive oil samples presented values within the allowed limit (2.5 to 232 $\mathrm{nm}$ and 0.22 to $270 \mathrm{~nm}$ ), being in agreement with the Brazilian legislation in force.

However, it is worth mentioning that there are other obligatory analyzes that must be done so that the olive oil can receive its classification as iodine index, absolute refractive index and composition of fatty acids. In addition, other nonmandatory analyzes that can assure the identity and quality of the oil, such as: composition of sterols, erythrodiol and uvaol content, stigmastadiene, ECN42, Delta-K and triacylglycerols composition, it is possible to more safely evaluate the identity and the quality [17].

Figure 1 represents the behavior of the overall assessment by the tasters. PC 1 and 2 are 2 components that best explain this acceptance, adding up to around $60 \%$. Each line (vector) individually represents each taster. These vectors are distributed almost randomly, showing that all cultivars have a similar degree of acceptance, perhaps with a slightly higher acceptance for the cultivars Maria da Fé and Grappolo 541 and a lower acceptance for Arbosana. We also noticed that there are 4 distinct groups, where the cultivars Koroneiki and Arbequina form the same group because they are closer and the other 3 have different behavior.

\section{Conclusions}

The results achieved by the study allow us to:

There are differences among the olives and olives oil produced by different cultivars in the South of Minas Gerais.

The cultivar Grappolo 541 produces bigger fruits, indicated for the preparation of olives for the consumption in natura.

Due to the small size of the fruit, the cultivar Maria da Fé is more suitable for the production of olive oil. 


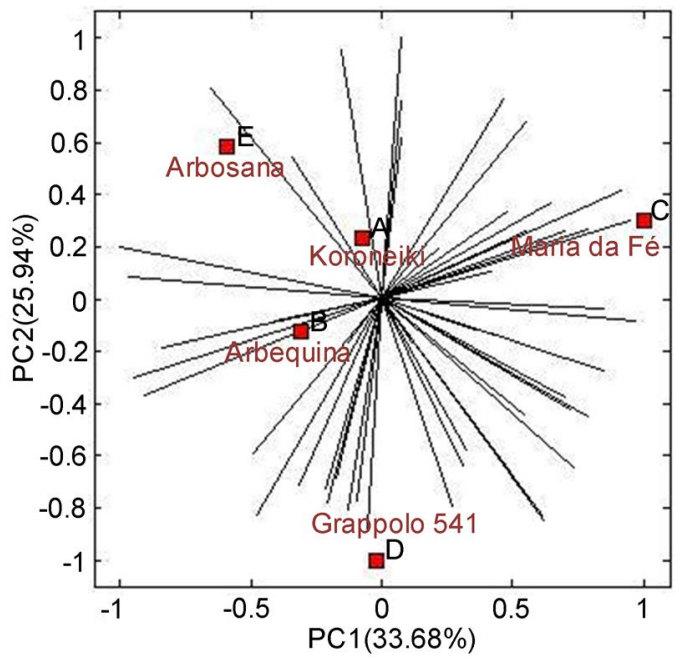

Figure 1. Sensory analysis of the global evaluation of olives oil extracted from olives (Principal Components-PC 1 and 2). A: Koroneiki, B: Arbequina, C: Maria da Fé, D: Grappolo 541 and E: Arbosana). EPAMIG/ UFLA, Lavras, Brazil, 2016.

The olive oils of all cultivars are within the parameters established by current Brazilian legislation, classified as Extra Virgin Olive Oil.

All olive oils are well accepted by consumers, especially the cultivars Maria da Fé and Grappolo 541.

\section{Acknowledgements}

The authors thank the Minas Gerais Research Support Foundation (FAPEMIG) and the Agricultural Research Company of Minas Gerais (EPAMIG) for the financial support.

\section{References}

[1] Silva, L.F.O. (2011) Agroindustrial Characterization of Olive Cultivars with Economic Potential for the South of Minas Gerais. Universidade Federal de Lavras, Lavras.

[2] Oliveira, A.F., Antunes, L.E.C. and Schuch, M.W. (2006) Morphological Characterization of Olive Cultivars in Collection and Considerations about Their Cultivation in Brazil. Informe Agropecuário, 27, 55-62.

[3] Forbes Brasil (2017) Brazil is the World's Leading Importer of Olive Oil. http://www.forbes.com.br/colunas/2015/06/brasil-e-vice-mundial-na-importacao-d e-azeite-de-oliva/

[4] Barcelos, M.F.P., Angelis-Pereira, M.C. and Oliveira, A.F. (2006) Nutritional Aspects of Olive Oil and Its Influence on Human Diet. Informe Agropecuário, 27, 98-104.

[5] Aparicio, R. and Harwood, J. (2013) Handbook of Olive Oil: Analysis and Properties. Springer, New York, 769. https://doi.org/10.1007/978-1-4614-7777-8

[6] Bester, E., et al. (2007) Chemical Changes in Extra Virgin Olive Oils from Slovenian Istra after Thermal Treatment. Food Chemistry, 108, 446-454.

https://doi.org/10.1016/j.foodchem.2007.10.061 
[7] Pimentel, I.C., Magnoni, C.D. and Costa, R.P. (2007) Use of Olive Oil in the Prevention and Treatment of Cardiovascular Diseases. Departments of SOCESP, São Paulo.

[8] Dutra, L.F., et al. (2004) Olive (Olea europaea L.) in Vitro Multiplication. Ciência e Agrotecnologia, 28, 220-223. https://doi.org/10.1590/S1413-70542004000100030

[9] ANVISA-National Sanitary Surveillance Agency (2016) Technical Regulation for Identification and Quality of Vegetable Oils and Fats. http://www4.anvisa.gov.br/base/visadoc/CP/CP\%5B8994-1-0\%5D.pdf

[10] Wikipedia (2016) Maria da Fé. http://pt.wikipedia.org/wiki/Maria da F\%C3\%A9

[11] Ferreira, D.F. (2008) Sisvar: A Program for Analysis and Teaching of Statistics. Revista Symposium, 6, 36-41.

[12] ANVISA (2005) Technical Regulation for Vegetable Oils, Vegetable Fats and Vegetable Cream. Official Gazette [da] Federative Republic of Brazil, Brasília.

[13] Association of Official Analytical Chemists (2005) Official Methods of Analysis of the Association of Official Analytical Chemists. Association of Official Analytical Chemists, Washington DC, 1410.

[14] Adolfo Lutz Institute-IAL (2005) Analytical Standards of the Adolfo Lutz Institute: Chemical and Physical Methods for Food Analysis. Adolfo Lutz Institute, São Paulo, 1, 533 .

[15] Pinheiro, A.C.M., Nunes, C.A. and Vietoris, V. (2013) SensoMaker: A Tool for Sensorial Characterization of Food Products. Ciência e Agrotecnologia (UFLA), 37, 199-201. https://doi.org/10.1590/S1413-70542013000300001

[16] Ministry of Agriculture, Livestock and Supply-MAP (2012) http://sistemasweb.agricultura.gov.br/sislegis/action/detalhaAto.do?method=visuali zarAtoPortalMapa\&chave $=629707739$

[17] Uceda, M., Hermoso, M. and Aguilera, M.P. (2008) The Quality of Olive Oil. In: Barranco, D., Fernández-Escobar, R. and Rallo, L., Eds., The Cultivation of the Olive Tree, Mundi-Prensa-Junta de Andalucía, Madrid, 699-727.

\section{Scientific Research Publishing}

Submit or recommend next manuscript to SCIRP and we will provide best service for you:

Accepting pre-submission inquiries through Email, Facebook, LinkedIn, Twitter, etc. A wide selection of journals (inclusive of 9 subjects, more than 200 journals)

Providing 24-hour high-quality service

User-friendly online submission system

Fair and swift peer-review system

Efficient typesetting and proofreading procedure

Display of the result of downloads and visits, as well as the number of cited articles

Maximum dissemination of your research work

Submit your manuscript at: http://papersubmission.scirp.org/

Or contact as@scirp.org 